\title{
Homossexualidade e perversão no campo da psicanálise
}

\section{Homosexuality and perversion in the field of psychoanalysis}

\author{
Richard Harrison Couto ${ }^{1}$, Tayane dos Santos Lage ${ }^{2}$
}

\begin{abstract}
Resumo
No campo da psicanálise ainda há grande confusão em relação à homossexualidade e perversão. Não é incomum ver a homossexualidade ser incluída, por muitos, no campo das perversões. Principalmente nas obras de Freud, onde alguns autores mencionam que o Freud se refere à homossexualidade como um exemplo de perversão, trazendo uma contradição e ambiguidade. O termo perversão, muitas vezes, é visto como algo pesado, ligando a ideia de ser aquilo que não é o principal e o não genital. Desse modo, o presente artigo tem como objetivo demonstrar o que os textos de Freud ainda podem fazer oposição aos equívocos que ainda são cometidos em relação às suas obras. Com o intuito de alcançar os objetivos propostos, foi feita uma pesquisa bibliográfica, na qual os resultados obtidos foram de que segundo Freud, a homossexualidade se trata de uma escolha de objeto sexual, tal como é uma escolha de um objeto para o heterossexual; a homossexualidade do mesmo modo que a heterossexualidade passa a ser uma prática sexual localizada em qualquer uma das estruturas clínicas e segundo Lacan todo ser humano pode situar de um lado ou do outro na partilha dos sexos, independente do sexo genético, hormonal, anatômico ou social.
\end{abstract}

Palavras-chave: Homossexualidade; perversão; psicanálise.

\begin{abstract}
In the field of psychoanalysis there is still confusion about homosexuality and perversion. It is not uncommon to see homosexuality included by many in the field of perversions. Especially in Freud's works, where some authors mention that Freud refers to homosexuality as an example of perversion, bringing a contradiction and ambiguity. The term perversion is often seen as heavy, linking the idea of being that which is not the main and the non-genital. Thus, the present paper aims to demonstrate what Freud's texts can still oppose the misunderstandings that are still committed in relation to his works. In order to reach the proposed objectives, a bibliographical research was done. The results obtained were that: according to Freud, homosexuality is a choice of sexual object, being either a choice of a heterosexual object; Homosexuality in the same way that heterosexuality happens to be a sexual practice located in any of the clinical structures; And according to Lacan every human being can situate from one side or the other the sharing of the sexes, regardless of the genetic, hormonal, anatomical or social sex. Keywords: Homosexuality. Perversion. Psychoanalysis.
\end{abstract}

1 Psicanalista. Doutor em Psicanálise pela Universidade do Estado do Rio de Janeiro. Professor do Curso de psicologia da Universidade Estácio de Sá (RJ).

2 Graduanda do curso de psicologia da Universidade Estácio de Sá, unidade de Santa Cruz (RJ). 


\section{Introdução}

A homossexualidade, em uma primeira leitura freudiana, chegou a ser pensada como uma forma de perversão e ainda há alguns mal-entendidos dentro do próprio campo psicanalítico. Como observa Ferraz (2010), esse desentendimento teve auxílio por conta de uma das obras de Freud publicada em 1905, a saber, os Três ensaios sobre a teoria da sexualidade, na qual para Ferraz, Freud contribuiu para a elaboração desta confusão, pela forma ambígua e contraditória com que levou a questão, assegurando a radicalidade de sua tese da contingência do objeto sexual e simplesmente citando a homossexualidade (ou inversão, como aparece nos Três ensaios...) como exemplo de perversão, sem dar maiores explicações.

Está confusão pode ser estabelecida porque nesta obra, os Três ensaios sobre a teoria da sexualidade, Freud (2016b) ainda descrevia a perversão como uma forma de desvio relativo à meta sexual, pois este dizia que a meta sexual normal seria a união dos genitais no ato denominado copulação, que leva à resolução da tensão sexual e um arrefecimento temporário da pulsão sexual, porém Freud (2016b), logo argumenta que mesmo no ato sexual mais normal já se observa os rudimentos que desenvolvidos, levam aos desvios que são denominados perversões. Além disso, Freud afirma que existem certas relações intermediárias com o objeto sexual, que se encontram no rumo da copulação, como por exemplo, tocar e olhar, que são tidas como metas sexuais provisórias.

O termo perversão guarda uma carga muito pesada e também negativa até hoje, porque, para o senso comum, ela está ligada a maldade, maucaratice, perversidade, vício, doença etc. (QUINET, 2013a) A palavra perversão tem a mesma ascendência do termo perversidade e isso leva a um desentendimento com relação aos dois termos (MARTINHO, 2013). O primeiro é utilizado com frequência no plural, que é designado como um comportamento que muitas vezes é relacionado ao ato sexual de uma pessoa; o segundo termo significa uma disposição constante do caráter, que remete a algo agressivo, também é vista como uma crueldade, algo maligno, que é designado ao fazer o mal em outrem (LANTERI-LAURA, 1994).

Porém o que nos interessa não é o que se passa no senso comum e sim no campo da psicanálise, assim, Barbero (2005) afirma que em suas pesquisas no campo da psicanálise, a ideia de algum tipo de desvio continuava, em todos os autores e argumenta que a perversão mostrava-se intrincada as questões homossexuais e que em suas pesquisas ao procurar o assunto da homossexualidade não conseguia achála sem estar ligada a perversão.

Para dar início a este trabalho, cabe explicar como era a homossexualidade na antiguidade; os estudos anteriores sobre o assunto; mencionar alguns autores que em seus textos apresentam equívocos em relação à homossexualidade e perversão; citar a homossexualidade nas obras de Freud; fazer uma breve demonstração da perversão nas obras do mesmo; e falar sobre a partilha dos sexos da teoria lacaniana, uma vez que, Lacan sempre parte de Freud. O interesse pelo tema não é de responder aos que estão externos a psicanálise e sim, justamente, ao que persiste dentro da própria psicanálise. A pesquisa, realizada para este artigo, permitiu trazer alguns apontamentos sobre a questão, podendo compartilhá-los para todos os interessados no tema.

$\mathrm{O}$ artigo tem o objetivo principal de rebater os equívocos cometidos por determinadas leituras das obras de Freud, que ainda persistem em relação à homossexualidade e perversão, através de um estudo das próprias obras freudianas, ou seja, usaremos $a$ letra de Freud para tal objetivo.

Foi feita uma pesquisa bibliográfica, que é realizada através de levantamentos de bibliografias já publicadas. A pesquisa bibliográfica corresponde a um levantamento de todas as bibliografias publicadas, tais como livros, documentos mimeografados ou fotocopiados e publicações avulsas. "Pesquisa Bibliográfica: quando elaborada 
a partir de material já publicado, constituído principalmente de livros, artigos de periódicos e, atualmente, material disponibilizado na Internet" (GIL apud KAUARK; MANHÃES; MEDEIROS, 2010, p. 28).

Toda pesquisa de certo modo, em psicanálise, é uma pesquisa clínica, contudo a pesquisa clínica não está confinada apenas a um papel de exploração ou de formulação de hipóteses novas que cabem na abordagem experimental validar, ao contrário, o que a psicanálise demonstra é que há possibilidade de fazer uma pesquisa que se fundamenta no caso a caso ou na singularidade (SAURET, 2003). Outro ponto importante a destacar, é que segundo Sauret, há diferentes tipos ou formas de pesquisa em psicanálise, ele diz que há "a que visa a responder a questões colocadas pela psicanálise; a que visa responder as questões colocadas à psicanálise; a que visa a construir uma teoria a partir da doutrina e da experiência; a que visa a ampliar o campo da experiência analítica" (SAURET, 2003, p. 99) e a última forma que o autor cita, pode-se inscrever este artigo, ou seja, esta pesquisa é "orientada pelo saber e eventualmente pela ética da psicanálise" (SAURET, 2003, p. 99).

Assim, foi feita uma leitura cuidadosa das bibliografias psicanalíticas, principalmente das obras de Freud e Lacan, pois foi necessário utilizar as obras lacanianas uma vez que, mencionaremos autores que também tiveram uma interpretação duvidosa de suas obras, mesmo envolvendo também em suas interpretações as obras de Freud.

Além de seu objetivo principal, o artigo tem os objetivos de: Verificar a afirmação de Freud de que a homossexualidade se trata de uma escolha de objeto sexual, podendo ser tanto uma escolha de um objeto homossexual ou heterossexual; demonstrar que a homossexualidade do mesmo modo que a heterossexualidade passa a ser uma prática sexual localizada em qualquer uma das estruturas clínicas; e demonstrar a afirmação de Lacan de que todo ser humano pode situar de um lado ou de outro na partilha dos sexos, independente do sexo genético, hormonal, anatômico ou social.

\section{A Homossexualidade Antes de Freud}

Na antiga Grécia e em Roma, a homossexualidade entre os homens não era apenas difundida de maneira comum, também era tida como a imagem ideal do erotismo e como o próprio modelo de educação dos jovens. Alguns dos maiores filósofos daquela época estavam de acordo com essas práticas e em incentivar os adolescentes a terem essas relações. Em Roma, essas práticas também eram comuns, a homossexualidade era corriqueira, não havia nenhuma regulamentação concernente a ela até o século III d.C., tal regulação incidia sobre os casos de violação de menores ou de casamentos entre homens, que era muito comum naquela época (ANDRÉ, 1995).

$\mathrm{Na}$ antiguidade, as leis sociais e sexuais traduzem o fato de que, para as pessoas daquela época, a diferença sexual era concebida conforme o modelo da dualidade senhor/escravo. O que era considerado monstruoso ou contrário à natureza, não era o fato do sujeito ter relações sexuais com outra pessoa do mesmo sexo, porém o de aceitar uma posição passiva, quando era um homem livre. No mundo antigo, o ponto importante era não ser escravo, não ser passivo. Ser ativo, ser senhor, isso era símbolo de masculinidade. Assim a homossexualidade ativa estava no mesmo patamar da heterossexualidade e a homossexualidade passiva era rejeitada (ANDRÉ, 1995).

Stoller também argumenta sobre a questão da homossexualidade na Grécia antiga e diz "Diferentes analistas leram os fatos diferentemente, alguns acreditaram que essa homossexualidade não era uma perversão, pois ela era aceita por toda a cultura; já outros acreditaram que a cultura, como um todo, era perversa" (STOLLER, 2015, p. 114). Vanggaard descrevia a homossexualidade, a que era aceitável entre os gregos, como sendo exclusiva 
para a classe mais alta, e restrita aos homens, tida como uma forma honrosa de relacionamento que era transmitida como os mais apurados padrões éticos da sociedade (VANGGAARD apud STOLLER, 2015).

Ainda em nossos dias objeções oriundas das religiões, principalmente da vertente cristã, recaem sobre a homossexualidade, porém, "contrariamente ao que se poderia pensar, parece que não foi a religião cristã como tal que esteve na origem da condenação radical da homossexualidade" (ANDRÉ, 1995, p. 120), pois não há nada constando nas escrituras, a não ser por uma passagem extremamente curta do Levítico XVIII, 22 e XX, 13, que não justifica a virulência nem a importância central reconhecida na moral cristã. Somente na idade média é que ocorreu uma identificação com o pecado dos sodomitas com a homossexualidade, daí o significado da palavra sodomia, que é preservado até hoje (ANDRÉ, 1995). Só depois das invasões dos bárbaros no século VI é que uma nova moral começou a aparecer e não teve nenhuma ligação com a obra do cristianismo em si (ANDRÉ, 1995). Contudo, no século XIII, São Tomás de Aquino lançou sua suma teológica às bases de condenação cristã aos atos homossexuais como sendo contra a natureza, ou seja, está contra a propagação da espécie humana e condena os homossexuais, colocando-os no mesmo nível dos animais, que praticam atos sexuais entre membros do mesmo sexo (TORRÃO, 2000).

\section{Investigações Sobre a Inversão Sexual (Homossexualidade)}

Em 1860 surgiram as primeiras brochuras de Ulrichs, primitivamente assinadas pelo pseudônimo Numa Numantius. Este autor que criou o termo uranista, que designa o amor sexual dos homens entre si. Ulrichs, que também era homossexual, defendia o uranismo e pedia o casamento entre pessoas do mesmo sexo, alegando que tinham os mesmos direitos que os heterossexuais. $\mathrm{O}$ autor escreveu alguns livros, mas era demasiado livre na linguagem, apaixonado nas suas considerações e por esse motivo seus livros perderam um pouco do valor que deveriam ter se fossem mais cuidados (SILVA, 2014). Segundo Krafft-Ebing, Ulrichs falhou, no entanto, em tentar provar que este sentimento sexual congênito e paradoxal era fisiológico e não patológico (KRAFFT-EBING, 1892, tradução nossa $)^{3}$.

Griesinger deu o primeiro passo para tentar explicar a origem biológica da homossexualidade através de suas próprias observações, apontando uma marcada contaminação hereditária do indivíduo (GRIESINGER apud KRAFFT-EBING, 1892, tradução nossa). Em 1870 Westphal, que era aluno de Griesinger, publicou o Archiv fur psychiatrie, foi o primeiro a colocar o estudo da inversão sexual (homossexualidade) numa base cientifica sólida. Ele a definia como uma afeição congênita e não adquirida, não acreditava que podia ser um vício. Embora o autor tenha observado a presença de elementos neuróticos, nunca registrou nada que pudesse ser considerado insano. Deu a esta condição o nome de sensibilidade sexual contrária. Posteriormente, foram publicadas diversas obras, principalmente na Alemanha, sobretudo no Archiv fur psychiatrie (ELLIS, 2012).

No início de sua investigação, Westphal considerou a inversão como um sinal funcional de degeneração, uma manifestação parcial de um estado neuropático e psicopático que na maioria das vezes seria hereditário; segundo esse autor tal sexualidade perversa apareceria espontaneamente com o decorrer da vida sexual, sem causas externas, como manifestação individual de uma alteração anormal, que ele chamava de vita sexualis, e a considerava congênita (ELLIS, 2012). Ele também acreditava nos casos da inversão adquirida, que é o resultado de influências de causas emocionais acidentais (KRAFFT-EBING, 1892, tradução nossa). Assim,

${ }^{3}$ KRAFFT-EBING (1892). Psychopathia sexualis. (Originalmente Publicado em 1886). 
as relações sexuais com o mesmo sexo resultavam da sedução ocasional ou dos sentimentos de amizade que, no nível da sexualidade patológica, associamse a sentimentos sexuais (KRAFFT-EBING, 1892, tradução nossa).

Gley acredita que ele é capaz de resolver o enigma da inversão pela teoria de que os homens que têm esses sentimentos sexuais contrários têm um cérebro feminino e glândulas sexuais masculinas; e, além disso, que as condições patológicas cerebrais determinam a vida sexual, enquanto que os órgãos sexuais determinam as funções sexuais do cérebro (GLEY apud KRAFFT-EBING, 1892, tradução nossa).

Segundo Krafft-Ebing o tratamento para instintos sexuais contrários, além da hipnose, são os seguintes: 1. Prevenção do onanismo e remoção de outras influências prejudicial à vita sexuali; 2. Cura da neurose decorrente das condições não higiênicas da vida sexual; 3. O tratamento mental, no sentido de combater os homossexuais, e incentivando a heterossexualidade, os sentimentos e os impulsos. A parte mais importante do tratamento reside no cumprimento da terceira indicação (KRAFFTEBING, 1892, tradução nossa).

Além destes citados acima, há muitos outros autores que investigaram a inversão sexual, são eles: Leonpacher; Hollander; Kriese; Chevalier; Golenko; Ritti; Tamassia; Lombroso; Síriex; Kiernan; Schrenk-Notzing; Moll Ellis (2012) e Havelock Ellis.

\section{Autores que Apresentam Equívocos em Relação à Perversão e Homossexualidade na Psicanálise}

Neste tópico argumentaremos sobre as afirmações de três autores, que são: Elisabeth Roudinesco, Waldermar Zusman e Checcinato. Os textos dos dois últimos autores foram escolhidos, por serem artigos da revista de psicanálise Boletim de Novidades - Pulsional, uma revista atual, bem conhecida e respeitada no campo psicanalítico e acadêmico.

Primeiro iremos apresentar a afirmação de Waldermar Zusman. O referido autor faz uma interpretação biologizante do entendimento sobre a pulsão, na qual ele negligencia a diferença que há entre o conceito de pulsão e de instinto, afirmando que "a atividade sexual se impõe aos seres humanos, bem como aos animais, sem se importar com o fato de que a chamemos de instinto ou pulsão" (ZUSMAN, 1997, p. 7-8). Esta visão biologizante, além de reduzir a Trie $^{4}$ freudiana ao instinto sexual, sustenta a versão de Zusman sobre a identificação do homossexual com a mãe enquanto fator responsável pela fixação anal e sua respectiva passividade. Apoiado na noção biológica das fases da libido em detrimento da linguagem, o autor faz existir o objeto capaz de completar o sujeito e, assim, sustenta sua crença de que a homossexualidade seria um desvio da norma por não ter se subordinado à primazia genital (ZUSMAN, 1998).

Porém, de maneira oposta à ideia que Zusman propõe, podemos entender nos textos de Freud, que há algumas características da pulsão que a distinguem de um instinto: o seu objeto não é prédeterminado biologicamente e as suas maneiras de satisfação são variáveis (FREUD, 2010). Este debate sobre o termo certo, instinto ou pulsão ainda é visível, e nas obras freudianas traduzidas para o português não há um consenso, por exemplo, as traduções da editora Imago e da Companhia das letras utilizam o termo "instinto", já a tradução das Obras incompletas de Sigmund Freud da editora Autêntica utiliza o termo "pulsão".

O segundo texto analisado é de Durval Checcinato, também analisado por Barbero (2005), que argumenta que escolheu esse texto porque é um texto onde há ideias que representam mais ou menos

\footnotetext{
${ }^{4}$ Palavra alemã que significa pulsão ou instinto para algumas tradutoras
} 
as posturas de psicanalistas atuais, especialmente lacanianos. No artigo de Checcinato, encontra-se trechos com ideias confusas, como por exemplo, o autor diz que os perversos buscam análise, porém na medida em que a análise desenvolve uma barreira para à sua satisfação, eles rapidamente se retiram. E afirma que "é o que pode acontecer, sobretudo (com) os homossexuais e transexuais" (CHECCINATO, 1997, p. 11). Há uma ideia confusa, ou seja, a afirmação de que através de uma passagem ao ato, tais analisandos têm capacidade de se tornarem analistas (CHECCINATO, 1997). Outro argumento do autor é "sobretudo a perfuração, tão característica nos homicídios de homossexuais, parece-me ser a procura paranoica de uma vagina que não existe e que cruelmente se acaba fabricando, mas para mergulhar no real da morte, o único que pode conter o fantasma da ambivalência" (CHECCINATO, 1997, p. 13).

Checcinato mistura perversão com a homossexualidade, talvez estas ideias equivocadas do autor tenham relação com o que Lacan dizia, alegando que os analistas cuidam dos homossexuais, porém não os curam, mesmo que sejam completamente curáveis (LACAN, 1999). Porém, Lacan abandona a ideia de uma cura para os homossexuais, pois no Seminário, livro XX, Mais ainda, de 1972-1973, Lacan foca nas explicações sobre as posições sexuais em termos de sexuação. É facultado ao falasser colocar-se no lado homem, ou no lado mulher, das fórmulas de sexuação. São João da Cruz é referido como um sujeito que se situou com afinidade no lado mulher das fórmulas (LACAN, 1985).

Por último, falaremos sobre a autora Elisabeth Roudinesco (2013) que é uma historiadora da psicanálise e psicanalista respeitada.Apresentaremos um trecho do capítulo $A$ psicanálise à prova da homossexualidade, produzido pela autora, que se encontra no livro As homossexualidades na psicanálise: na história de sua despatologização, no qual a autora afirma que:
Dito isso, Lacan não tinha a mesma concepção que Freud da homossexualidade. A seu ver, com efeito, ela não tem nada a ver com uma orientação sexual. Personagem altamente transgressivo, Lacan era marcado pela leitura das obras de Sade e por seu contato com Georges Bateille. Sua fascinação pela homossexualidade grega levava-o, de uma parte, a fazer da figura do perverso a encarnação da mais alta intectualidade - ainda que maldita - e, de outra, a ver toda forma de amor - até mesmo de desejo - como algo perverso. Assim como Lacan 'psicotiza' a clínica das neuroses, do mesmo modo, tende a ver perversão em todas as manifestações do amor. É nesse contexto que ele faz da homossexualidade, enquanto tal, uma perversão e não uma orientação sexual (ROUDINESCO, 2013, p. 113).

Roudinesco (2013) faz uma leitura equivocada dos textos lacanianos, pois nas obras de Lacan não há nenhuma constatação de tais argumentos, portanto não parece correto afirmar que Lacan via toda forma de amor como algo perverso. A autora também utiliza o termo orientação sexual, visto que Freud nunca utilizou esse termo, logo o termo correto, utilizado por Freud é escolha sexual.

\section{Freud e a Homossexualidade}

$\mathrm{Na}$ teoria freudiana, a pulsão sexual não se resume na divisão do ser humano em duas metades homem e mulher, porém encontram uma surpresa, ao saber que existem homens para os quais o objeto sexual não é a mulher, mas sim outros homens, e mulheres que o objeto sexual não é o homem, e sim uma mulher. Essas pessoas são chamadas de invertidas, hoje chamados de homossexuais (FREUD, 2016b).

Esses indivíduos se comportam de maneiras diferentes e em diversos aspectos, tais como: a) São absolutamente invertidos, seu objeto sexual pode ser somente do mesmo sexo, enquanto o sexo oposto nunca é visto como objeto de anseio sexual, podendo causar até aversão; b) São invertidos anfígenos (hermafroditas psicossexuais), com isso, 
o objeto sexual tanto pode pertencer ao mesmo sexo como ao outro; não há o caráter de exclusividade à inversão; e c) São invertidos ocasionais, ou seja, em algumas condições externas, entre as quais se encontram, primeiramente, a inacessibilidade do objeto sexual normal e a imitação, podem tomar outra pessoa do mesmo sexo como objeto sexual e ter satisfação com ela no ato sexual (FREUD, 2016b).

Freud aponta que o primeiro entendimento que se tem da inversão consistiu em vê-la como algo inato de degeneração nervosa, isso se harmoniza com o fato dos observadores médicos terem encontrado primeiramente em doentes nervosos ou em pessoas que davam a impressão de ser. Com isso existem duas coisas que devem ser destacadas; o caráter inato e a degeneração (FREUD, 2016b). Porém, Freud afirma que a homossexualidade não deve ser explicada nem com a hipótese de que seria inata e nem que seria adquirida. Pois no primeiro caso, é preciso explicar o que nela é inato, a não ser que se admita a crua explicação de que uma pessoa nasce com a pulsão sexual ligada a um objeto sexual determinado. No outro caso, a questão é se as diversas influências acidentais seriam o bastante para explicar a aquisição, sem que alguma coisa no sujeito lhe venha ao encontro. Negar esse último fator não seria possível; pois teria que afirmar que muitas pessoas tiveram as mesmas influências sexuais na primeira infância, tais como: sedução e masturbação mútua (FREUD, 2016b).

Sobre a teoria da bissexualidade foi enunciado de maneira rudimentar por um porta-voz dos homossexuais masculinos: "cérebro de mulher em corpo de homem". Porém não se conhece as características de um cérebro de mulher. Substituir um problema psicológico por um anatômico é desnecessário e injustificado (FREUD, 2016b).

Em relação à meta sexual, ao contrário do que se pensa no caso dos homens, o intercurso pelo ânus não coincide absolutamente com a inversão; a masturbação, também é frequente. No caso das mulheres as metas também são variadas, porém parece ser privilegiado o contato com a mucosa da boca (FREUD, 2016b).

Nesta obra o autor usa diversas vezes o termo normal para se referir à heterossexualidade. Isto pode levar a uma má interpretação do termo, como algo sadio e do anormal como patológico. Porém, a partir da posição ética de Freud e de seus textos em relação à moral sexual, pode-se entender a palavra normal, utilizada por ele, como relativo à norma social e o anormal como sendo algo proibido pela sociedade (QUINET, 2013b).

\section{Leonardo da Vinci e uma Lembrança da sua Infância}

Em 1910, Freud analisou os poucos fatos conhecidos sobre a vida de Leonardo da Vinci, investigando as inibições em sua vida sexual, como também suas atividades artísticas, sua infância; e nesse texto Freud traz contribuições importantes sobre a questão da homossexualidade.

Para iniciar sua análise, Freud situa o que vem a ser pulsão de saber, que se estabelece quando o período de pesquisa sexual infantil termina, após um período de enérgico recalque sexual, o impulso de pesquisa terá três possíveis diferentes vicissitudes, que teve resultado de sua relação primitiva com interesses sexuais (FREUD, 1996). No primeiro caso, a pesquisa participa do destino da sexualidade; portanto, a curiosidade continuará inibida e a liberdade da atividade intelectual poderá continuar a ser limitada durante todo o decorrer de sua vida, sobretudo porque, logo a seguir, a influência da educação causará uma intensa inibição religiosa do pensamento. Esse é o tipo que se caracteriza por uma inibição neurótica. O enfraquecimento intelectual obtido nesse processo representa um fator efetivo na irrupção de uma enfermidade neurótica (FREUD, 1996).

No segundo tipo, o desenvolvimento intelectual é suficientemente forte para resistir ao recalque 
sexual que o domina. Algum tempo depois o fim das pesquisas sexuais infantis, a inteligência, tendo se tornado mais forte, recorda a antiga associação e ajuda a evitar o recalque sexual, e as suprimidas atividades sexuais de pesquisa emergem do inconsciente sob a forma de uma preocupação pesquisadora compulsiva, naturalmente sob uma forma distorcida e não livre, porém bastante forte para sexualizar o próprio pensamento e colorir as operações intelectuais, com o prazer e a ansiedade característicos dos processos sexuais. Neste caso, a pesquisa torna-se uma atividade sexual, diversas vezes a única, e o sentimento que advém da intelectualização e explicação das coisas substitui a satisfação sexual; mas o caráter interminável das pesquisas infantis é também repetido no fato de que está preocupação jamais termina e que o sentimento intelectual, tão desejado, de alcançar uma solução, torna-se cada vez mais distante (FREUD, 1996).

Leonardo possui o terceiro tipo, que é o mais raro e mais perfeito, pois escapa tanto a inibição do pensamento quanto ao pensamento neurótico compulsivo. Nele também existe o recalque sexual, mas ele não consegue relegar para o inconsciente nenhum componente pulsional do desejo sexual. Ao invés disso, a libido escapa ao destino do recalque sendo sublimada desde o princípio em curiosidade e ligando-se a poderosa pulsão de pesquisa como uma maneira de se fortalecer. A pesquisa também se torna, até certo ponto, compulsiva e funciona como substitutivo para atividade sexual; mas devido à total diferença nos processos psicológicos subjacentes; ou seja, sublimação ao invés de um retorno ao inconsciente, a qualidade neurótica não está presente; não existe ligação com os complexos originais da pesquisa sexual infantil e a pulsão pode agir livremente a serviço do intelectual (FREUD, 1996).

Pode-se refletir acerca da ocorrência, em Leonardo, dessa poderosa pulsão de pesquisa restrita ao que se pode chamar de homossexualidade ideal sublimada, pois depois de sua curiosidade ter sido ativada, na infância, a serviço de interesses sexuais, conseguiu sublimar a maior parte da sua libido em sua ânsia pela pesquisa (FREUD, 1996). Freud levanta a hipótese de que Leonardo é um homem de sentimentos homossexuais e diz que o que classifica alguém como homossexual não é o seu comportamento real, mas sim a sua atitude emocional (FREUD, 1996).

Com isto, pode-se relacionar com o que Freud afirma que são três determinantes da sexualidade: a anatomia; a posição subjetiva, ou seja, masculina ou feminina; e a escolha sexual, homossexualidade ou heterossexualidade. Então, observa-se que com Freud, através do conceito de pulsão, este retira a sexualidade do campo completamente do puro orgânico. E Lacan a partir do retorno a Freud vai nos mostrar que a sexualidade é completamente desnaturalizada pela linguagem, pelo inconsciente. Sendo assim estabelece que a diferença sexual se repercute nas posições subjetivas de gozo e na diferença de posição entre o todo e o não todo fálico não sendo dependente de qualquer genitália (QUINET, 2016).

Quando se pensa na probabilidade histórica de Leonardo ter se comportado em sua vida como uma pessoa emocionalmente homossexual, Freud teve a hipótese de que a homossexualidade de Leonardo pode ter a ver com uma relação causal entre as relações infantis de Leonardo com a mãe, resultando posteriormente em uma homossexualidade manifesta, mesmo sendo sublimada (FREUD, 1996).

Em todos os casos de homossexuais masculinos na psicanálise, os indivíduos tinham uma ligação erótica muito intensa com uma mulher, em geral sua mãe, durante o primeiro período de sua infância, sendo esquecida posteriormente, esta ligação resulta pela demasiada ternura por parte da mãe, e depois foi reforçada pelo papel secundário desempenhado pelo pai durante sua infância. Mas o pai de Leonardo não esteve presente em sua infância, deixando o menino sob a influência feminina. A presença de um pai forte assegura, no filho a escolha correta de objeto, 
ou seja, uma pessoa do sexo oposto (FREUD, 1996). Daí pode-se dizer que a escolha do objeto é balizada pela dissolução do complexo de Édipo

Após esse estágio preliminar o amor da criança pela mãe é recalcado; o menino recalca o amor pela mãe; coloca-se em seu lugar, se identifica com ela e toma a si próprio como um modelo a que deve ser parecido com os novos objetos de seu amor. Dessa maneira ele se torna um homossexual (FREUD, 1996). Segundo Lacan (1979) pode-se dizer que a escolha do parceiro de gozo é conduzida por elementos preferenciais, que dizendo de outra forma, são traços significantes que vem do Outro. Esses traços podem variar, todavia eles são em números limitados, traços que são retirados do Outro como lugar do significante. Esses traços simbólicos oferecerão os atributos do objeto sexual, eles são determinados, inscritos no inconsciente. São de fato traços do Outro que podem ser traços do pai, mãe, avó, avô etc. (QUINET, 2006). Assim:

O sujeito se esforça para manter suas relações de objeto a qualquer preço, utilizando todas as espécies de acomodações nesse objetivo: mudanças de objeto com o uso do deslocamento, ou da simbolização, que, pela escolha de um objeto simbólico arbitrariamente investido dos mesmos valores afetivos do objeto inicial, vai the permitir não se ver privado de relações objetais (LACAN, 1995, p. 19).

A escolha simbólica de objeto é uma maneira de não perder o objeto (QUINET, 2013a). Ao lado do determinado existe o indeterminado que caracteriza o lugar de A Coisa, La Chose, aquilo que foge ao julgamento, ou seja, a qualquer atributo; pode-se vinculá-la ao encontro, portanto, a tykhés (QUINET, 2006).

$\mathrm{O}$ que aconteceu na verdade foi um retorno ao auto-erotismo, porque os meninos que agora ele ama, à medida que cresce, são apenas figuras substitutivas e lembrança dele mesmo no período da infância, seguindo o modelo do narcisismo (FREUD, 1996). O homem, em alguns casos se torna homossexual quando permanece inconscientemente fixado à imagem mnêmica de sua mãe, recalcando seu amor à sua mãe, o conserva por meio da identificação e, desse modo, permanece-lhe fiel (FREUD, 1996).

Em Lacan é possível pensar que em toda escolha amorosa se localiza o fundamento narcísico da imagem ( $i$ ) com seus mecanismos de identificação e projeção, próprios do registro imaginário, e também o registro real do objeto $(a)$ que confere a dimensão de desejável para o parceiro. Pode-se ler o matema i (a) que escreve o outro imaginário, o semelhante, como portando o objeto causa de desejo (QUINET, 2013a).

\section{Freud e a Perversão}

Na sua obra Três ensaios sobre a teoria da sexualidade Freud (2016b) apresenta pela primeira vez o conceito de perversão. Freud (2016b) faz alusão à perversão polimorfa da criança, indicando que, em toda criança a satisfação advém das diversas zonas erógenas do corpo, ele também postula que o prazer está relacionado a certas fixações ligadas às fases da sexualidade infantil, que continuam registradas no psiquismo e contribuem para a confirmação da sexualidade genital de cada um na vida adulta. Trata-se da permanência na vida adulta de características perverso-polimorfas, típicas da sexualidade pré-genital infantil, em detrimento da sexualidade genital.

Freud (2016b), no caso Dora, definiu as neuroses como o negativo da perversão, pois nas neuroses os impulsos perversos, depois de terem sido recalcados, manifestam-se a partir do inconsciente, embora em ambas as estruturas psíquicas tenham determinações

\footnotetext{
${ }^{5}$ Lacan em O seminário livro 11, de 1964, pega emprestada de Aristóteles, a palavra tykhé, em contraponto ao Automaton, que significa o retorno, a volta, é o que Lacan designa por insistência dos signos aos quais são governados pelo princípio do prazer. Tykhé, assim, é o encontro do real, e o real é o que vigora sempre atrás do Automaton.
} 
e formulações diferentes uma da outra, assim como têm mecanismos diferentes, o recalque para a neurose e desmentido da castração para a perversão; além de haver manifestações distintas, por exemplo, a fantasia recalcada na neurose e a fantasia posta em cena na perversão. No entanto, elas são iguais em um aspecto, as duas têm sua origem na sexualidade infantil.

No texto Fetichismo, Freud (2016a) inicia dizendo que em suas investigações observou que para alguns homens a escolha de objeto é dominada por um fetiche e coloca o fetiche como substituto para o pênis da mulher. Cabe explicar que Freud (1976a) afirma que as crianças elaboram "teorias sexuais" que se referem a uma primeira "busca pelo saber". "Uma dessas teorias consiste em atribuir a todos as pessoas, incluindo as mulheres, um pênis".

O menino vê os órgãos genitais de uma irmãzinha ou companheira de brincadeira, logo suspeita de que há algo diferente, e tenta efetuar tentativas de repetir suas observações, de maneira a buscar mais esclarecimentos. Encobrem a contradição entre a observação e a preconcepção pensando que o pênis ainda é pequeno e ficará maior logo, e depois lentamente chegam à conclusão de que, o pênis estava lá, antes e fora retirado depois. A falta de um pênis é vista como resultado da castração e, agora, a criança se depara com a tarefa de chegar a um acordo com a castração em relação a si mesma (FREUD, 1976a).

Assim, o fetiche é um substituto do pênis, porém não é qualquer pênis, trata-se de um pênis específico e muito especial, que teve uma grande importância nos primeiros anos da infância e que depois foi perdido. Para dizer especificamente o fetiche é o substituto para o falo da mulher (da mãe) (FREUD, 2016a).

O que ocorre foi que o menino se recusa a tomar conhecimento do fato de que a mulher não possui o pênis. Pois para ele se a mulher é castrada, seu próprio pênis está ameaçado, e contra isso se rebela a parte do seu narcisismo, com o qual a natureza precavidamente dotou esse órgão (FREUD, 2016a). Freud afirma que "o adulto provavelmente irá vivenciar um pânico semelhante quando for proclamado que o trono e o altar estão em perigo, e esse pânico levará a consequências ilógicas semelhantes" (FREUD, 2016a, p. 316).

Neste texto Freud aponta um novo mecanismo de defesa em relação à castração, agora não se trata do recalque, que em alemão é Verdrangung, mas sim de uma recusa da realidade, a Verleugung, uma parte da realidade é recusada pelo Eu. Neste caso com o fetiche há tanto uma recusa à realidade quanto uma afirmação da castração (FREUD, 2016a).

Com o horror à castração, o fetichista ergue para si um monumento na criação desse substituto. $\mathrm{O}$ substituto do falo continua como signo do triunfo sobre a ameaça da castração e como proteção contra ela. Seguindo essa lógica, pode-se pensar que com o horror da castração, todo fetichista tende a ser homossexual, porém isso não acontece porque o fetichista com seu fetiche empresta à mulher a característica através da qual ela se torna suportável como objeto sexual (FREUD, 2016a).

\section{Homossexualidade não é Perversão}

Com Freud (2016b), a perversão foi despatologizada ao situar que toda criança é perversa polimorfa e que a sexualidade continua infantil no adulto, Freud (2010d) apontou que a sexualidade é perversa, porque a pulsão sempre se satisfaz parcialmente, usando de uma parte do corpo do parceiro como um objeto. Indica, deste modo, que a sexualidade é norteada pelas pulsões, que são, por estrutura, perversas. Existe, portanto, o universal da perversão na sexualidade do ser falante (QUINET, 2013b). A perversão generalizada inclui a prática tanto heterossexual quanto homossexual, pois o que sempre está em jogo para as pulsões é o objeto, que pode ser qualquer um (FREUD, 2010d).

A homossexualidade não se resume à estrutura perversa, ela pode ser encontrada na estrutura 
neurótica (histeria, obsessão e fobia), na psicose (esquizofrenia, paranoia e melancolia) e na perversão (voyeurismo, fetichismo, sadismo, masoquismo etc.). Quinet (2013b) ressalta muito bem isto quando diz "a homossexualidade, como prática sexual, não é, desse modo, um sintoma neurótico, não é uma perversão e nem é indício de loucura. A homossexualidade é transestrutual. Ela é uma escolha de gozo do sujeito que se encontra em neuróticos, perversos e psicóticos" (QUINET, 2013b, p. 91). Em todos os grandes casos de Freud, encontramos algum tipo de homossexualidade, sem que esta seja resumida a uma prática sexual, como por exemplo: na histeria de Dora, na fobia de Hans, na esquizofrenia-paranoide de Schreber, na paranoia do Homem dos Lobos e na vida sexual da jovem homossexual (QUINET, 2013b).

Podemos observar isto na histeria de Dora, no que se refere a este caso clínico, Freud fala sobre as inclinações homossexuais de Dora dizendo que por trás da forte linha de pensamentos vinculada à relação do pai de Dora com a sra. K. existe também, um impulso ciumento, cujo objeto era a sra. K, um impulso, deste modo, que apenas podia se basear na inclinação pelo mesmo sexo. Freud ainda diz que em rapazes e garotas, na fase da puberdade, podem aparecer indícios da existência de inclinação homossexual (FREUD, 2016b).

No caso do pequeno Hans, Freud destacou que Hans poderia ser considerado um homossexual, "(como todas as crianças podem muito bem ser), devido ao fato, que precisa ser sempre mantido em mente, de que ele só estava informado quanto a um tipo de órgão genital - um órgão genital como o seu" (FREUD, 1976b, p. 117-118).

No caso de Schreber, no desencadeamento de sua psicose, em sua primeira fase, o que se observa, é que, embora haja as suas tentativas de ir contra as fantasias homossexuais, estas não recuaram, pelo contrário, manifestam-se em um delírio de transformação em mulher, que Schreber passa a experimentar em seu corpo e em suas vísceras.
Pela via da construção de um delírio persecutório, Schreber atribui essa emasculação imposta, sentida no real de seu corpo, a uma perseguição e uma grande injúria que era dirigida ao seu médico Flechsig. Esta fantasia de desejo feminino, Freud chama de homossexualidade passiva. Uma grande resistência a essa fantasia ergue-se do lado da personalidade de Schreber, e a luta defensiva veio em forma de delírio de perseguição. $O$ médico Flechsig que era ansiado tornou-se o perseguidor. $\mathrm{O}$ conteúdo da fantasia de desejo tornou-se o conteúdo da perseguição (FREUD, 2010c).

Schreber depois substitui, em seu delírio, a figura do médico pela superior figura de Deus, pois se era impossível conciliar-se com o papel de mulher diante do médico, não acha a mesma resistência do Eu à tarefa de conceder ao próprio Deus a volúpia que ele pede. A emasculação já não é uma desgraça, vem a ser conforme a ordem do mundo, toma seu lugar em um grande contexto cósmico (FREUD, 2010c). Freud argumenta que observa a irrupção de um impulso homossexual como o embasamento da psicose de Schreber (FREUD, 2010c).

No caso do homem dos lobos, após a sedução por parte da irmã, tentou seduzir Nanya, sua governanta, tocando seu pênis na presença desta, porém seus investimentos foram recusados, depois disso veio a consequente supressão do início da atividade sexual, a vida sexual do garoto desenvolveu-se na direção do sadismo e do masoquismo. O seu sadismo conservava sua identificação com o pai; porém, no masoquismo, escolhia-o como objeto sexual. Aprofundava-se numa fase da organização pré-genital (FREUD, 2010a).

$\mathrm{Na}$ operação do sonho com os lobos, que o colocou sob a influência da cena primária, ou seja, a cena que o homem dos lobos presenciou do coito dos pais, podia tê-lo conduzido a fazer o avanço no sentido da organização genital e a modificar o masoquismo em relação ao pai numa atitude feminina, ou seja, em uma homossexualidade. O sonho, entretanto, não ocasionou esse avanço. 
Esperava-se que sua relação com o pai prosseguisse do objetivo sexual de ser espancado para o objetivo seguinte, ou seja, o de ser possuído por ele, como uma mulher. Porém, devido à oposição da sua masculinidade narcísica, essa relação foi lançada de volta para uma etapa ainda mais primitiva, foi deslocada para um substituto paterno e, ao mesmo tempo, dissociada em um medo de ser devorado pelo lobo. A partir do período do sonho, em seu inconsciente, ele era homossexual e, em sua neurose, estava no nível do canibalismo; ao passo que a atitude anterior, masoquista, permaneceu dominante (FREUD, 2010a).

No caso da jovem homossexual, Freud analisa a questão da homossexualidade feminina no amor, onde o autor investiga o caso de uma jovem homossexual, que demonstra interesse por mulheres mais velhas. A jovem é levada pelo pai até Freud, pois o pai queria que sua homossexualidade fosse curada. Porém Freud afirma que a sexualidade normal é baseada em uma restrição do objeto, e, de maneira geral, o fato de transformar em heterossexual um homossexual não é mais promissora do que ao contrário (FREUD, 2011a).

A jovem homossexual analisada por Freud não apresentava desvio da compleição física feminina, tampouco algum distúrbio menstrual, porém a menina apresentava um tipo de comportamento masculino, perante o seu objeto amoroso (perante a dama que amava), ou seja, mostrava a humildade e a enorme superestimação sexual do homem apaixonado. Ela não tinha escolhido um objeto feminino, mas assumido uma postura masculina. A análise demonstrou que a menina trouxe da infância um complexo de masculinidade, pois não queria ficar na sombra do irmão, ela desenvolveu uma forte inveja do pênis. Ela na verdade era uma feminista; achava injusto que as meninas não pudessem ter as mesmas liberdades dos meninos (FREUD, 2011a).

Como podemos observar, em todos os casos citados, a homossexualidade aparece e não se resume a um ato sexual e muito menos a estrutura perversa. Assim se deve distinguir, em Freud, o que ele chama de pulsão ou tendência homossexual, que é um componente libidinal de todo ser humano, e a homossexualidade exercida na prática como escolha de objeto efetivada pelo sujeito, sendo consciente ou inconsciente (QUINET, 2013a).

Freud vai ainda mais longe na despatologização da homossexualidade, em seu Manuscrito inédito de 1931 (FREUD, 2017), elaborado para ser o prefácio de um livro escrito com o embaixador norteamericano William C. Bullitt sobre o ex-presidente norte-americano Thomas Woodrow Wilson, ele afirma que é devido à uma libido homossexual sublimada que a humanidade faz laço social, que há união entre os homens, aqui cabe citar Freud: "a própria sociedade humana se mantém unida por meio de libido homossexual sublimada, na medida em que a passividade do menino em direção ao pai se transforma em amor ao próximo a serviço da sociedade" (FREUD, 2017, p. 86). Ora, cabe o questionamento, se a homossexualidade estivesse na perversão completamente, seria possível uma libido homossexual manter a humanidade unida por todos esses anos? Freud ainda salienta que não é só laço social, unidade entre homens, que a libido homossexual mantém, ele coloca que tal libido garante a continuidade da humanidade: "é a homossexualidade, não em sua forma manifesta, mas em suas sublimações, que garante a continuidade da comunidade humana e talvez consiga um dia unificar todas as raças da humanidade em uma grande fraternidade" (FREUD, 2017, p. 87). Na citação vemos mais, a esperança de Freud de uma fraternidade, de uma sociedade sem preconceitos, está depositada na libido homossexual. Podemos dizer que a perversão implica numa certa exclusão, num certo "preconceito", pois só serve o objeto que corresponde ao fetiche, todos os outros objetos estão excluídos, logo o laço social sustentado é tênue. 


\section{A homossexualidade como Escolha de Objeto}

$\mathrm{O}$ assunto em relação à escolha foi introduzido cedo na psicanálise, por Freud (1913), com a expressão a escolha da neurose e posteriormente com o conceito de escolha de objeto sexual. Tanto no caso da escolha da orientação subjetiva, quanto no caso da escolha do parceiro sexual, trata-se de uma escolha relacionada ao gozo, sendo assim, de como o sujeito se situa em relação ao gozo (QUINET, 2006). Lacan, ao retomar esse termo nas operações de causação do sujeito com o conceito paradoxal de escolha forçada, indica que para a psicanálise não existe sujeito sem escolha, mesmo este sendo subvertido pela atividade do objeto mais-de-gozar (LACAN, 1988).

Pode-se destacar que a homossexualidade se trata de uma escolha de objeto e não de uma estrutura perversa, Freud demonstra isso em seus Três ensaios sobre a teoria da sexualidade, de 1905, onde diz:

A teoria popular do instinto sexual tem uma bela correspondência na fábula poética da divisão do ser humano em duas metades - homem e mulher -, que buscam unir-se novamente no amor. Resulta em grande surpresa, então, saber que existem homens para os quais o objeto sexual não é a mulher, mas o homem, e mulheres para as quais esse objeto não é o homem, mas a mulher (FREUD, 2016b, p. 21).

Em sua obra Três ensaios sobre a teoria da sexualidade, Freud (2016b) esclarece que não existe uma sexualidade determinada, sendo que esta é sempre polimorfa, e demonstrou que a homossexualidade é uma de suas nuances (PAOLIELLO, 2013). Ainda nos Três ensaios... Freud sustenta essa posição se baseando no complexo de Édipo, fundado sobre a bissexualidade original, pois apenas há a chamada escolha de objeto devido à bissexualidade original, no desenrolar da constituição subjetiva um dos objetos será escolhido, balizando o gozo. Assim, Freud argumenta que todos têm a possibilidade de escolher um objeto homossexual:

A investigação psicanalítica se opõe decididamente à tentativa de separar os homossexuais das outras pessoas, como um grupo especial de seres humanos. Estudando outras excitações sexuais além daquelas manifestadas abertamente, ela sabe que todas as pessoas são capazes de uma escolha homossexual de objeto e que também a fizeram no inconsciente [...]. Para a psicanálise, isto sim, a escolha objetal independente do sexo do objeto, a possibilidade de dispor livremente de objetos masculinos e femininos, tal como se observa na infância, em estados primitivos e épocas antigas, parece ser a atitude original, a partir da qual se desenvolvem como invertido. Na concepção da psicanálise, portanto, também o interesse sexual exclusivo do homem pela mulher é um problema que requer explicação, não é algo evidente em si, baseado numa atração fundamentalmente química (FREUD, 2016b, p. 34-35).

Ao desenvolver o complexo de Édipo e situando a bissexualidade nos fundamentos dessa estrutura, Freud demonstrou a posição sexuada, homem ou mulher enquanto escolha do sujeito, indo além da anatomia. Da mesma maneira, com o rochedo da castração, indissociável do Édipo, deu grande valor ao falo, enquanto significante da diferença dos sexos (MARQUES, 2013).

Freud argumenta que é possível demonstrar uma diferença, em relação à escolha sexual, pois quando o garoto se identifica com o pai, ele quer ser igual ao pai; quando o faz objeto de sua escolha, ele quer tê-lo; no primeiro caso seu Eu é alterado conforme o modelo do pai, no segundo isto não é necessário. A identificação e a escolha de objeto são, em ampla medida, independentes uma da outra; porém é possível alguém se identificar com a mesma pessoa que tomou por objeto sexual, alterando seu $\mathrm{Eu}$ segundo ela (FREUD, 2010b).

Sendo assim podemos ver que a decisão da escolha do objeto sexual está aberta desde a infância, e pode ser uma escolha tanto homossexual quanto heterossexual. 


\section{A Partilha dos Sexos em Lacan}

Destaca-se que a escolha do sexo é compreendida em seu duplo aspecto: como uma escolha da posição sexuada dentro da partilha dos sexos e como uma escolha de objeto sexual (QUINET, 2006). Freud diz que a posição sexuada e escolha de objeto são de âmbitos totalmente diferentes (FREUD, 2016b). Estar na posição feminina ou masculina é uma coisa; porém ter um homem ou uma mulher como objeto sexual é outra coisa (QUINET, 2013a). Lacan continua seguindo a mesma lógica com sua teoria da sexuação, demonstrando que "Quem quer que seja ser falante se inscreve de um lado ou de outro" (LACAN, 1985, p. 107), sendo assim todo ser humano pode se situar de um lado ou de outro na partilha dos sexos, independente do sexo genético.

Lacan introduz o termo sexuação justamente para demonstrar que a partilha entre os sexos não se faz pela anatomia, muito menos pela genética. A diferença sexual é construída nas fórmulas da sexuação a partir de argumentos da lógica localizando no lado dito masculino do todo fálico e o lado dito feminino do não todo fálico (LACAN, 1985).

O lado masculino é totalmente determinado e circunscrito pela função fálica, sendo assim assujeitado à castração simbólica (DIAS, 2008). Pois "[...] é pela função fálica que o homem como todo toma inscrição [...]" (LACAN, 1985, p. 107). O homem se assegura deste lugar de homem por meio da apropriação fálica, ou seja, da apropriação de objetos. Porém há uma exceção em que Lacan diz:

Exceto que essa função encontra seu limite na existência de um x pelo qual a função $\Phi x$ é negada, $\exists \mathrm{x} \overline{\Phi x}$. Aí está o que chamamos função do pai - de onde procede pela negação a proposição $\overline{\Phi x}$, o que funda o exercício do que supre, pela castração, a relação sexual - no que está não é de nenhum modo inscritível. O todo repousa, portanto, aqui, na exceção colocada, como termo, sobre aquilo que, esse $\overline{\Phi x}$, o nega integralmente (LACAN, 1985, p. 107).
Com isso Lacan (1985) conjuga o quantificador "para todo" com o quantificador "existe um que diz não". Esse que existe é o sujeito suposto de que aí a função fálica não compareça, sendo assim, há um que não é castrado.

Se a regra é castração simbólica para todos os homens, é preciso estruturalmente que haja uma exceção, fora do universal da castração, que fale não à função fálica, $\exists x$ Фx. Este pelo-menos-um fora da função fálica do lado masculino da sexuação, como demonstra Lacan, que é alimentada pela função do pai (LACAN, 1985) que se pode encontrar no pai da horda primitiva que Freud (2011b) demonstra em Totem e tabu, onde Freud retoma Charles Darwin, o qual demonstrou uma hipótese sobre o estado dos homens primitivos, para desenvolver sua teoria do pai primordial (FREUD, 2011b).

Freud constrói um mito procedente da humanidade, em que existia um homem que ditava as leis e a quem pertenciam todas as mulheres; os filhos deste homem não tinham como rivalizar com ele, embora cobiçassem suas mulheres (FREUD, 2011b). "Chega um momento em que esses outros homens - os filhos do um homem - decidem matá-lo, e assim o fazem" (ALBERTI, 2009, p. 171). Morto, o homem todo-poderoso não pode mais impedir a desordem que se designa, sem leis, a comunidade ligeiramente chega à beira do desaparecimento. Os filhos desse homem decidem, então, fazer com que sua imagem volte e erguem um totem, que veneram, mas ao mesmo tempo passam a se sentirem culpados pelo assassinato que cometeram. Criamse os tabus, como por exemplo, o incesto, que são leis ligadas ao totem, às quais a comunidade precisa obedecer (FREUD, 2011b). É por esse motivo que, em psicanálise, a Lei sempre está referida ao pai, autor da castração que, ao nomear os filhos como seus, impõe-lhes limites que eles, contudo, sempre tentarão derrubar (ALBERTI, 2009).

O mito do pai da horda primitiva produz consistência imaginária à verdade da "todohominia" (QUINET, 2012), ou seja, da castração como função 
fálica para todo homem. $\mathrm{O} \exists \mathrm{x} \overline{\Phi x}$ compõe um limite ao gozo fálico, demonstra que o gozo fálico é limitado, contém uma borda, não é infinito. Esse limite é a castração, simbolicamente efetuada pelo Pai edipiano (LACAN, 1985).

Estruturalmente, aponta que seu regulador é a norma fálica, que dá a medida para o homem. Os homens estão sempre se medindo, competindo, avaliando, comparando seus falos. Esses estão totalmente na norma fálica, a qual compõe o gozo fálico e sua limitação (QUINET, 2012).

O homem se assegura deste lugar de homem por meio da apropriação fálica, ou seja, da apropriação de objetos; de cargos, de prestígio, de realizações. Isso porque ele tampouco tem o falo, como a angústia de castração, aponta. Isso o induz não a temer perdêlo, já que não o tem, mas a arranjar substitutos cuja perda, aí sim, significaria sua castração (QUINET, 2012).

Em relação ao lado feminino, Lacan diz:

[...] a inscrição da parte mulher dos seres falantes. A todo ser falante, como se formula expressamente na teoria freudiana, é permitido, qualquer que ele seja, quer ele seja ou não provido dos atributos da masculinidade - atributos que restam a determinar - inscrever-se nesta parte. Se ele se inscreve nela, não permitira nenhuma universalidade, será nãotodo, no que tem a opção de se colocar na $\Phi x$ ou bem de não estar nela (LACAN, 1985, p. 107).

Este lado é diferente do lado masculino, pois não há o um fundante, que não tenha passado pela castração, o que impossibilita ter um universal de referência para a castração feminina, logo é o que demonstra o discurso analítico, no que, para um desses seres como sexuados, para o homem enquanto portador do órgão dito fálico, o sexo corporal, o sexo da mulher, ainda que justamente não exista a mulher, a mulher não é toda, o sexo da mulher não lhe diz nada, a não ser por meio do gozo do corpo (LACAN, 1985).
Lacan propõe, para se pensar nesta lógica, a lógica da heteridade, que não compõe universo ou grupo, é paradoxalmente um conjunto aberto (QUINET, 2017). Não é uma lógica da medida por medida, da competição, da batalha para saber quem tem o maior, da luta para ver quem tem mais: "Heteros é o âmbito do incomensurável. E do um a um, um mais um mais um que não se fecha num todo. É o âmbito do sem razão e de um gozo para além do fálico" (QUINET, 2017, p. 30). Sendo assim, o feminino é o Sempre-Outro (QUINET, 2017).

O termo, heterossexual é “por definição, aquele que ama as mulheres, qualquer que seja seu sexo próprio" (LACAN, 2003, p. 467). Está posição é definida por aquele que é amado, que se encontra no lado do não todo fálico, independente do sexo.

Sendo assim todo ser humano pode situar de um lado ou do outro na partilha dos sexos, independente do seu sexo genético, hormonal, anatômico ou social. Com isso, tanto para Freud quando para Lacan, a questão da homossexualidade se trata de uma escolha. Para Freud uma escolha de objeto sexual e para Lacan uma escolha inconsciente de gozo.

\section{Considerações Finais}

Neste artigo foi abordado o tema da homossexualidade e perversão no campo da psicanálise, pois ainda existe muita confusão em relação à homossexualidade e perversão tanto no senso comum quanto no próprio campo da psicanálise. Não é incomum ver a homossexualidade ser incluído na estrutura perversa, principalmente relacionadas às obras de Freud. O método utilizado para a pesquisa foi à pesquisa bibliográfica, foi feito uma leitura das obras psicanalíticas em relação à perversão e a homossexualidade, tendo como fonte principalmente as obras de Freud.

Baseado no que foi estudado, conclui-se que as obras de Freud ainda são capazes de responder as críticas que ainda são feitas a ele. Pode-se destacar 
que a homossexualidade se trata de uma escolha de objeto e não de uma estrutura perversa, pois quando Freud explica a teoria das pulsões sexuais, este diz que a sexualidade se trata de uma escolha de objeto, e que há homens que escolhem outros homens como objeto sexual, e há mulheres que escolhem outras mulheres como objeto sexual.

Freud realmente chega a dizer que os desvios das metas sexuais são denominados como perversões, ou seja, a meta que não seja a união dos genitais no ato denominado copulação, porém Freud explica que há certas relações intermediárias com o objeto sexual, que se encontram no rumo da copulação, como por exemplo, o ato de tocar, olhar e até mesmo beijar, que segundo o autor tem grande valor sexual em muitas civilizações, mesmo que essas partes do corpo não pertençam ao aparelho sexual. Ainda enfatiza que esses elementos permitem relacionar as perversões com a vida sexual, tida como normal pela sociedade.

$\mathrm{Na}$ teoria de Lacan também há uma escolha sexual, pode-se observar isto na partilha dos sexos, em sua teoria da sexuação, onde afirma que qualquer ser humano, independente do seu sexo genético, pode se encontrar em um dos lados da partilha dos sexos, sendo assim um homem pode estar do lado feminino (não-todo fálico) e uma mulher pode estar no lado masculino (todo-fálico). Com isto a afirmação da psicanalista Elisabeth Roudinesco de que Lacan não via a homossexualidade como uma orientação sexual, e de que não seguia a mesma concepção de Freud não faz sentido. Aliás, o termo orientação sexual, não seria o termo correto, pois se trata de uma escolha em relação ao gozo e para a psicanálise não existe sujeito sem escolha, como dito anteriormente.

Conclui-se também que a homossexualidade, assim como a heterossexualidade pode se dar em todas as estruturas ou não, ambas podem ser uma prática que podem ocorrer em neuróticos que apresentam seus sintomas; em perversos com seus fetiches e preferências sexuais ou em psicóticos com seus delírios.
Portanto entende-se que todas as hipóteses e objetivos foram atingidos. Porém a pesquisa continuará, porque ainda existem desentendimentos em relação à homossexualidade e perversão, pois percebe-se que há preconceitos e um mal-entendido em relação a este tema no próprio campo da psicanálise, o que de fato é preocupante.

\section{Referências}

FREUD, S. Algumas consequências psíquicas da distinção anatômica entre sexos (1925). In: _. . O ego e o ID e outros trabalhos. Rio de janeiro: Imago, 1976a. p. 303-322. (Edição Standard Brasileira das Obras Psicológicas Completas de Sigmund Freud, v. 19).

FREUD, S. Análise de uma fobia em um menino de cinco anos (1909). In: Duas histórias clínicas (O "Pequeno Hans" e o "Homem dos ratos"). Rio de Janeiro: Imago, 1976b. p. 11-154. (Edição Standard Brasileira das Obras Psicológicas Completas de Sigmund Freud, v. 10).

FREUD, S. Fetichismo. In: Neurose, psicose, perversão. Belo Horizonte: Autêntica, 2016a. v. 5, p. 315-325.

FREUD, S. História de uma neurose infantil ["O homem dos lobos", 1918 [1914]. In: História de uma neurose infantil ("O homem dos lobos"), além do principio do prazer e outros textos [1917-1920]. São Paulo: Companhia Das Letras, 2010a. p. 9-107. (Obras completas, v. 14).

FREUD, S. Leonardo da Vinci e uma lembrança da sua infância (1910). In: Cinco lições de psicanálise, Leonardo da Vinci e outros trabalhos. Rio de Janeiro: Imago, 1996. p. 53-124. (Edição Standard Brasileira das Obras Psicológicas Completas de Sigmund Freud, v. 11).

FREUD, S. Manuscrito inédito de 1931. São Paulo: Blucher, 2017.

FREUD, S. Novas conferências introdutórias à psicanálise (1933). In: _ . O mal-estar na civilização, novas conferências introdutórias à psicanálise e outros textos. São Paulo: Companhia das Letras, 2010b. p. 123-354. (Obras completas, v. 18).

FREUD, S. Observações psicanalíticas sobre um caso de paranoia [Dementia Paranoides] relatado em autobiografia ["O caso Schreber", 1911]. In:

Observações psicanalíticas sobre um caso de paranoia relatado em autobiografia ["O caso Schreber"], artigos sobre técnica e outros textos. São Paulo: Companhia das Letras, 2010c. p. 13-107. (Obras completas, v. 10). 
FREUD, S. Os instintos e seus destinos (1915). In: Introdução ao narcisismo, ensaios de metapsicologia e outros textos. São Paulo: Companhia das Letras, 2010d. p. 51-81. (Obras completas, v. 12).

FREUD, S. Sobre a psicogênese de um caso de homossexualidade feminina (1920). In: Psicologia das massas e análise do Eu e outros textos. São Paulo: Companhia das Letras, 2011a. p. 101-131. (Obras completas, v. 15).

FREUD, S. Totem e tabu (1912-1913). In: Totem e tabu, contribuição à história do movimento psicanalítico e outros textos. São Paulo: Companhia das Letras, 2011b. p. 7-157. (Obras completas, v. 11).

FREUD, S. Três ensaios sobre a sobre a teoria da sexualidade (1905). In: - Três ensaios sobre a teoria da sexualidade, análise fragmentária de uma histeria ("O caso Dora") e outros textos. São Paulo: Companhia das Letras, 2016b. p. 13-19. (Obras completas, v. 6).

ALBERTI. S. Esse sujeito adolescente. Rio de Janeiro: Rios Ambiciosos, 2009.

ANDRÉ, S. A impostura perversa. Rio de Janeiro: J. Zahar, 1995.

BARBERO, G. H. Homossexualidade e perversão na psicanálise: uma resposta aos gays e lesbian studies. São Paulo: Casa do Psicólogo, 2005.

CHECCINATO, D. "Perversão". Pulsional, São Paulo, n. 93, p. 5-15, jan. 1997.

DIAS, M. G. L. V. Do gozo fálico ao gozo do Outro. Ágora, Rio de Janeiro, v. 11, n. 2, p. 253-266, jul. /dez. 2008.

KRAFFT-EBING, R. Psychopathia sexualis. Londres: The F. A. Davis CO Publishers, 1892.

ELLIS. H. Inversão sexual. Lisboa: INDEX ebooks, 2012. v. 2.

FERRAZ, F. C. Perversão: clínica psicanalítica. 5. ed. São Paulo: Casa do Psicólogo, 2010. v. 1

KAUARK, S. F.; MANHÃES, F. C.; MEDEIROS, C. H. Metodologia da pesquisa: guia prático. Salvador: Via Litterarum, 2010.

LACAN, J. O seminário: livro 1: os escritos técnicos de Freud. Rio de Janeiro: J. Zahar, 1979.

LACAN, J. O Seminário: livro 4: a relação do objeto. Rio de Janeiro: J. Zahar, 1995.

LACAN, J. O seminário, livro 5: as formações do inconsciente. Rio de Janeiro: J. Zahar, 1999.
LACAN, J. Letra de uma carta de amor. In: . $O$ seminário: livro 20: mais, ainda. 2. ed. Rio de Janeiro: J. Zahar, 1985. p. 105-120.

LACAN, J. O aturdito. In: de Janeiro: J. Zahar, 2003. p. 448-496. Outros escritos. Rio

LANTERI-LAURA, G. Leitura das perversões. Rio de Janeiro: J. Zahar, 1994.

MARQUES, L. Sexualidade e ética psicanalítica. In: QUINET, A.; JORGE, M. A. C. (Org.). As homossexualidades na psicanálise: na história de sua despatologização. São Paulo: Segmento Farma, 2013. p. 59-64.

MARTINHO, M. H. O caso Carlos: a natureza perversa do gozo. In: QUINET, A.; JORGE, M. A. C. (Org.). As homossexualidades na psicanálise: na história de sua despatologização. São Paulo: Segmento Farma, 2013. p. 255-262.

PAOLIELlO, G. A. Despatologização da homossexualidade. In: QUINET, A.; JORGE, M. A. C. (Org.). As homossexualidades na psicanálise: na história de sua despatologização. São Paulo: Segmento Farma, 2013. p. 29-46.

QUINET, A. A escolha do sexo com Freud e Lacan. In: QUINET, A.; JORGE, M. A.C. (Org.). As homossexualidades na psicanálise: na história de sua despatologização. São Paulo: Segmento Farma, 2013a. p. 131-140.

QUINET, A. A escolha do sexo. Heteridade: Revista de Psicanálise, Paris, v. 6, p. 1-210, 2006.

QUINET, A. Homo e hétero em Lacan. Cult, São Paulo, n. 8, p. 28-30, 2017.

QUINET, A. Homofobias psicanalíticas na psicologização do Édipo. Stylus, Rio de Janeiro, n. 33, p. 1-312, nov. 2016.

QUINET, A. Homossexualidades em Freud. In: QUINET, A.; JORGE, M. A. C. (Org.). As homossexualidades na psicanálise: na história de sua despatologização. São Paulo: Segmento Farma, 2013b. p. 89-105.

QUINET, A. Os outros em Lacan. Rio de Janeiro: J. Zahar, 2012.

ROUDINESCO, E. A psicanálise à prova da homossexualidade. In: QUINET, A.; JORGE, M. A. C. (Org.). As homossexualidades na psicanálise: na história de sua despatologização. São Paulo: Segmento Farma, 2013. p. 107-117.

SAURET, M. J. A pesquisa clínica em psicanálise. Revista de Psicologia da USP, São Paulo, v. 14, n. 3, p. 89-104, fev. /maio 2003. 
SILVA. A. P. A inversão sexual: estudos médico-sociais. Lisboa: INDEX ebooks, 2014.

STOLLER, R. J. Perversão: a forma erótica do ódio. São Paulo: Hedra, 2015.

TORRÃO, F. A. Tríbades galantes, fanchonos militantes: homossexuais que fizeram história. São Paulo: GLS/ Summus, 2000.
ZUSMAN, W. As Erínias da Celmy. Boletim Científico da SBPRJ, Rio de Janeiro, v. 1, p. 1-8, jan. 1998.

ZUSMAN, W. Breve anatomia da homossexualidade. $O$ Globo, Rio de Janeiro, 12 ago. 1997. Caderno Opinião, p. 7. 